\title{
An Assessment of Flexural Improvement of Light Weight Concrete via Hybrid Fibres along with Sisal Fibres in Addition to Banana Fibres
}

\author{
S. Southamirajan ${ }^{1, a^{*}}$, K. Anbarasi ${ }^{2, b}$, S. Elango ${ }^{3, c}$ Dhivyaprakash $^{4, d}$, B. Bharath4, ${ }^{, e}$ \\ ${ }^{1}$ Assistant Professor, Department of Civil Engineering in Kongunadu College of Engineering and \\ Technology, Trichy, Tamilnadu, India \\ ${ }^{2}$ Assistant Professor, Department of Civil Engineering in Kongunadu College of Engineering and \\ Technology, Trichy, Tamilnadu, India \\ ${ }^{3}$ Assistant Professor, Department of Civil Engineering in K.S.R.College of Engineering, \\ Namakkal, Tamilnadu, India \\ ${ }^{4}$ Bachelor's degree in Department of civil engineering in kongunadu college of Engineering and \\ technology, Trichy, Tamilnadu, India \\ *asouthamirajan@gmail.com, bkbanbuarun@gmail.com, cs.elango@ksrce.ac.in, \\ ddhivyaprakashappu@gmail.com, ebharath27091999@gmail.com
}

\section{Keywords: Lightweight Concrete, Sisal Fibre, Banana Fibre, Hybrid Fibre}

\begin{abstract}
Innate fibres, these days have become the topic of argument in the research field between different scientists to inculcate it in the formation of lightweight concrete mixture. This is due to a variety of rewards connected with natural fibres like recyclable, economical, availability in large quantity and its bio-degradability. Plenty of projects have been carried out in the production of natural fibre reinforced lightweight concrete. In this project, we would like to take the naturally existing fibre named sisal fibre and banana fibre as partial replacement material. The adding of natural fibre to the lightweight concrete will enhance the diverse strength parameters like flexural strength, compressive strength, and increase the ductile behaviour. In the current work, it is intended to explore the mechanical properties of lightweight concrete with substitution of sisal fibre and banana fibre for cement in different percentages. The compressive strength, flexural strength, deflection of the beam is calculated with the reflection of M30 concrete specimens. Totally 45 number of $500 \times 100 \times 100 \mathrm{~mm}$ flexural member, 45 numbers of cubes and 45 numbers of cylinders are cast and tested. It is suggested that up to $1.5 \%$ substitution of sisal fibres and banana fibre with cement provide at M30 grade of concrete giveing the most beneficial increases of strength values. The assessment outcome indicated that the sisal fibres and banana fibre were efficient in improving the performance of lightweight concrete
\end{abstract}

\section{Introduction}

A random try have been made in the earlier period to reduce the self weight of concrete to increase the effectiveness of concrete as a structural material [2]. Lightweight concrete (LWC) is a fascinating field of explore and has been extensively used in buildings since many decades. It has much reward such as better thermal insulation, sound assimilation, fire and frost control and increased seismic performance. The light-weight concrete is a concrete which has a density of 300 to $1850 \mathrm{~kg} / \mathrm{m}^{3}$ [4] .There are many benefits of having low density. It helps in reduction of deceased load, increases the augmentation of building. The self weight of a building on the foundation is a significant aspect, in case of loose soil and it can be rectified by using the light weight concrete as one of the way [5]. Air-conditioning is required in the structure where it is obtained by the using 
light weight concrete with low thermal conductivity will be appropriate [6]. The light weight concrete can be obtained by using industrial wastes such as clinker, fly ash, steel slag and bamboo etc. and by the addition of air in concrete.

Natural fibre has extraordinary application in the ground of civil Engineering [8]. Natural fibres are a good reinforcing substance. Sisal fibre shows prospective strengthening effect in light weight concrete on relation of its with low cost, ease of use, low density, non hazardous one, sustainable and high specific strength and modulus [9]. The configuration and properties of sisal fibre have been scrutinized by several researchers. Sisal fibre in reinforced concrete along with light weight concrete effect over other conventional material seems largely from their higher specific strength, stiffness and fatigue uniqueness which enable structural performance to be more adaptable.

\section{Materials Used}

\section{Cement}

Cement, a well accepted obligatory material, it is forever advantageous to use the finest cement in constructions. Consequently, the selection of cement may be varying on the type of construction. Ordinary Portland cement is available in three different grades of 33, 43, and 53. In this assignment, 53 grade ordinary Portland cement is used for the scrutinizing.

Table 1 Properties of cement

\begin{tabular}{ll}
\hline Properties & Value \\
\hline Fineness Modulus & 3.5 \\
Specific gravity & 2.9 \\
Consistency & $30.2 \%$ \\
Initial Setting Time & 30 Minutes \\
Final Setting Time & 1 Hour \\
\hline
\end{tabular}

Manufacturing Sand (M Sand)

M Sand is worn like a fine aggregate in this project. The sand used in this project where nearby procured. $\mathrm{M}$ sand is acknowledged as manufactured sand. It is a crushed aggregate product from hard granite stone which has irregular edges, washed and graded with consistency to be used as a replacement of river sand. The practice of $M$ Sand can overcome the defects taking place in concrete such as honeycombing, segregation, voids, capillarity etc. Usage of M-Sand can radically decrease the cost, it does not hold impurities and wastage.

Table 2 Properties of fine aggregates

\begin{tabular}{cc}
\hline Properties & Value \\
\hline Specific Gravity & 2.55 \\
Fineness Modulus & $2.65 \%$ \\
Water Absorption & $1.50 \%$ \\
Size & Passing through $4.75 \mathrm{~mm}$ sieve \\
\hline
\end{tabular}

Coarse Aggregate

The coarse aggregate obtained from the crushing plant is used in the present study. The physical parameters of coarse aggregate like specific gravity, water absorption and fineness modulus are tested in accordance with IS: 2386. The coarse aggregate used in this examination is of the dimension $20 \mathrm{~mm}$. It gives sufficient strength to the concrete. The aggregate takes up 70-80 per cent of the volume of the concrete. The meticulous selection of aggregate in any mix of concrete is chosen for their durability, strength, workability, and capability to obtain good results. 


\section{Table 3 Properties of coarse aggregates}

\begin{tabular}{cc}
\hline Properties & Value \\
\hline Fineness Modulus & 8.12 \\
Specific gravity & 2.9 \\
Water absorption & 2.8 \\
Size & $20 \mathrm{~mm}$ \\
\hline
\end{tabular}

\section{Coarse aggregate bamboo}

The bamboo is less in weight, elastic, hard, high durable with great tensile characteristic, and economical material than the other building materials. Bamboo can be used in a variety of building mechanism. Bamboo structures are good in flexibility, earthquake resistant nature with high torsion resistance, light weight and economical. Practice of bamboo may be lead for green buildings and sustainable growth, Bamboo can be used as bamboo flooring, decking, decorative paneling, and siding and as coarse aggregate for light weight concrete. Due to its natural characteristics of bamboo houses hold the both earthquake and cyclone resistant effects. In this project the bamboo are wrecked into a parts of required sizes associated to coarse aggregate and sieved through $4.75 \mathrm{~mm}$ sieve to eliminate the smaller particles.

Table 4 Properties of coarse aggregate bamboo

\begin{tabular}{cc}
\hline Properties & Value \\
\hline Fineness Modulus & 8.95 \\
Specific gravity & 0.6 \\
Water absorption & $21 \%$ \\
Size & $20 \mathrm{~mm}$ \\
\hline
\end{tabular}

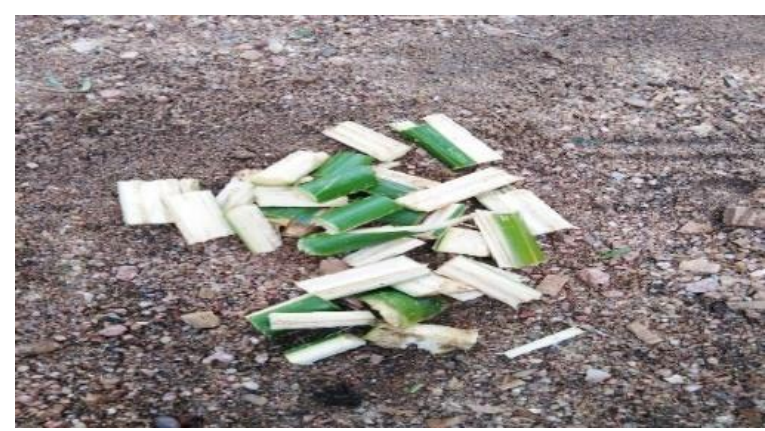

Figure 1 Bamboo

Sisal Fibre

Sisal fibre is one of the most important accepted natural fibres and is enormously easily cultivated with a lesser amount of water requirement. It has a small crop growing period and grows in nature in the cultivable and non-cultivable lands, the material is selected based on the improvement of different strength properties of the structure to gain sustainability and higher performance. Short distinct vegetable fibre (sisal) is examined for its appropriateness for merging in cement concrete. Sisal fibre requires only a little amount of process In the current investigation, sisal fibre is constantly used in all mix with different ratios. 
Table 5 Physical Properties of Sisal Fibre

\begin{tabular}{cc}
\hline Properties & Value \\
\hline Average length $(\mathrm{mm})$ & 300 \\
Average & 0.12 \\
Diameter(mm) & \\
Average Tensile & 1090 \\
Strength $\left(\mathrm{N} / \mathrm{mm}^{2}\right)$ & 18.2 \\
Elongation & $76.7 \%$ \\
Water Absorption & \\
$(\%)$ & \\
\hline
\end{tabular}

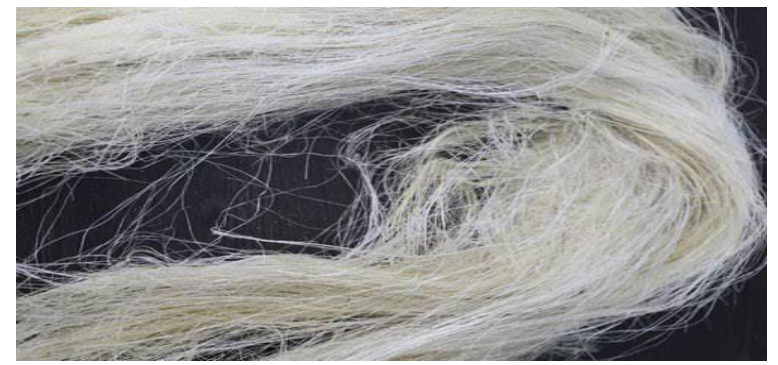

Figure 2 Sisal Fibres

\section{Banana Fibre}

The banana is a fibrous fraction casing the stem. It constitutes $25-45 \%$ of the total size of the fruit. Banana husk fibres are primarily constituted of hemicelluloses and not of cellulose. Banana fibres hold 13 to $24.6 \%$ of lignin, 35 to $64.8 \%$ of hemicelluloses, $4.4 \%$ of ash content and leftover 8 to $25 \%$ of water content. The fibres bordering the internal layer are unevenly lignified group of cells with banana fibres and the portions of the core coating surround soft fibres. Banana fibre is extremely hemi cellulosic and superior to that of any other fibres. The Properties of Banana fiber are given in table 2.6. Banana fibres are durable, tough, resistant, resilient and long-lasting. Banana fibre is a replacement in the mix with a percentage to the weight of cement

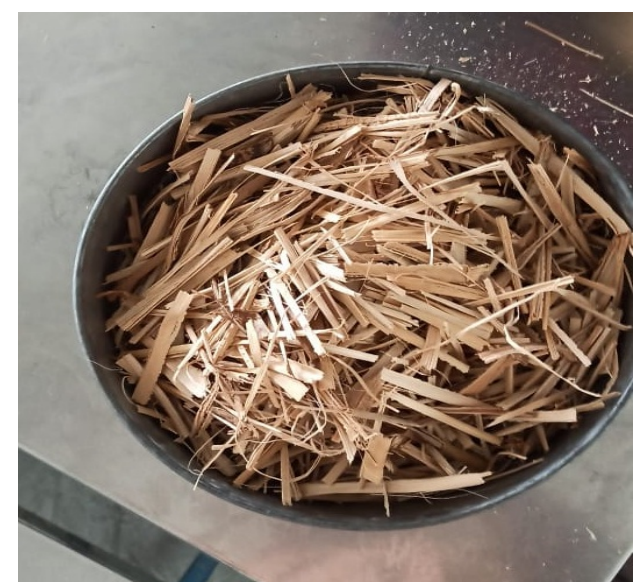

Figure 3 Banana Fibres 
Table 6 Physical Properties of Banana Fibre

\begin{tabular}{cc}
\hline Properties & Value \\
\hline Width(micron meter) & 250 \\
Density $\left(\mathrm{Kg} / \mathrm{m}^{3}\right)$ & 1150 \\
Initial Modulus(Gpa) & 5 \\
Tensile & 115 \\
strength(Mpa) & 35 \\
Elonagtion $(\%)$ & \\
\hline
\end{tabular}

Water

Amalgamation and curing is done by clean water, which was gratis from any other impurities like oils, acids, alkalis, sugar, salts, and organic ingredients that may be injurious to concrete or steel. The $\mathrm{pH}$ for clean water is supposed to not be less than 6 for concreting.

\section{Preparation and testing of specimen:}

General

The investigational work was planned to examine the mechanical properties like flexural behavior of concrete with $15 \%$ of replacement of coarse aggregate by bamboo and $1 \%, 1.5 \%, 2 \%$ and $2.5 \%$ of sisal fibres and banana fibre as hybrid fibre reinforced concrete with the weight of cement and for M30 grade of concrete all along with $0.1 \%$ of replacement of water with super plasticizer due to adding up of sisal fibres and banana fibre in concrete. The compressive strength of the cube, split tensile strength of cylinder and flexural behavior of the beam is analysis for 7, 14, 28 days.

For the test models, 53 grades Ordinary Portland Cement, M sand, coarse aggregate, bamboo, super plasticizer, sisal fibres and banana fibre are being analyses.

The greatest size of the coarse aggregate was restricted to $20 \mathrm{~mm}$. the concrete mix proportions of M30 grade with the water-cement ratio of 0.50 were utilized. The concrete mix was proposed to attain the flexural strength of $30 \mathrm{MPa}$ after 28 days curing period. The concrete beams $(500 \mathrm{~mm} \times$ $100 \mathrm{~mm} \times 100 \mathrm{~mm}$ ) for regular as well as other mixes were cast. Each layer was compacted with 25 blows using a $16 \mathrm{~mm}$ diameter rod.

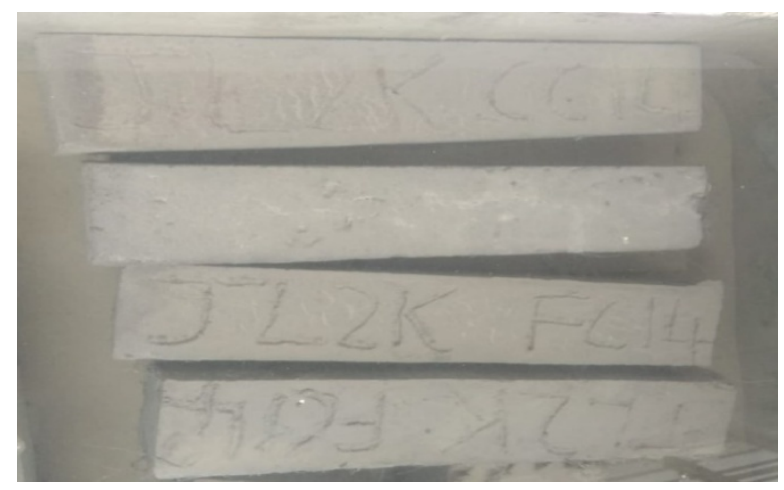

Figure 4 Test samples 
Table 7. Sample Specimen Details

\begin{tabular}{ccc}
\hline S.No & Specimens & Details \\
1 & Sample 1 & $\begin{array}{c}1 \% \text { sisal and banana fibre for weight of } \\
\text { cement and } 15 \% \text { bamboo for weight coarse } \\
\text { aggregate }\end{array}$ \\
2 & Sample 2 & $\begin{array}{c}1.5 \% \text { sisal and banana fibre for weight of } \\
\text { cement and } 15 \% \text { bamboo for weight coarse } \\
\text { aggregate }\end{array}$ \\
3 & Sample 3 & $\begin{array}{c}2 \% \text { sisal and banana fibre for weight of } \\
\text { cement and } 15 \% \text { bamboo for weight coarse } \\
\text { aggregate }\end{array}$ \\
4 & $\begin{array}{c}\text { Conventional } \\
\text { concrete }\end{array}$ & $\mathrm{M}_{30}$ grade of light weight concrete \\
\hline
\end{tabular}

Compressive strength test

The sample cubes of size $150 \mathrm{~mm} \times 150 \mathrm{~mm} \times 150 \mathrm{~mm}$ is cured for respective days as 7,14 and 28 days, the specimen is tested in compression testing machine with sample set as per date.

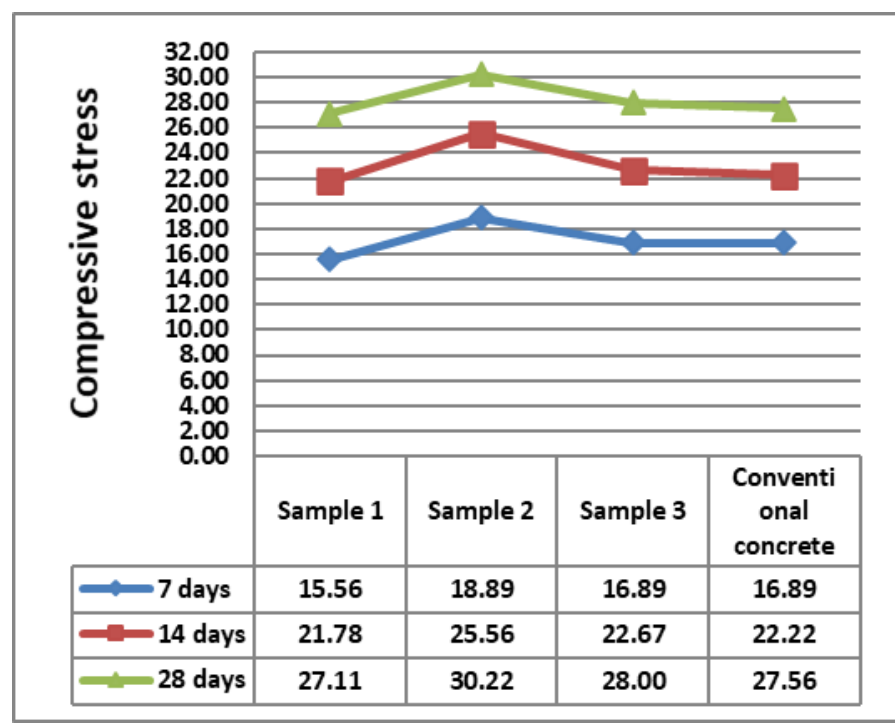

Figure 5 Graph Showing the Results of Compressive Strength of HFRC.

\section{Tensile Strength test}

The sample cylinder specimens shall be $150 \mathrm{~mm}$ in diameter and $300 \mathrm{~mm}$ long is cured for respective days as 7,14 and 28 days, the specimen is tested in compression testing machine with a sample set as per date. 


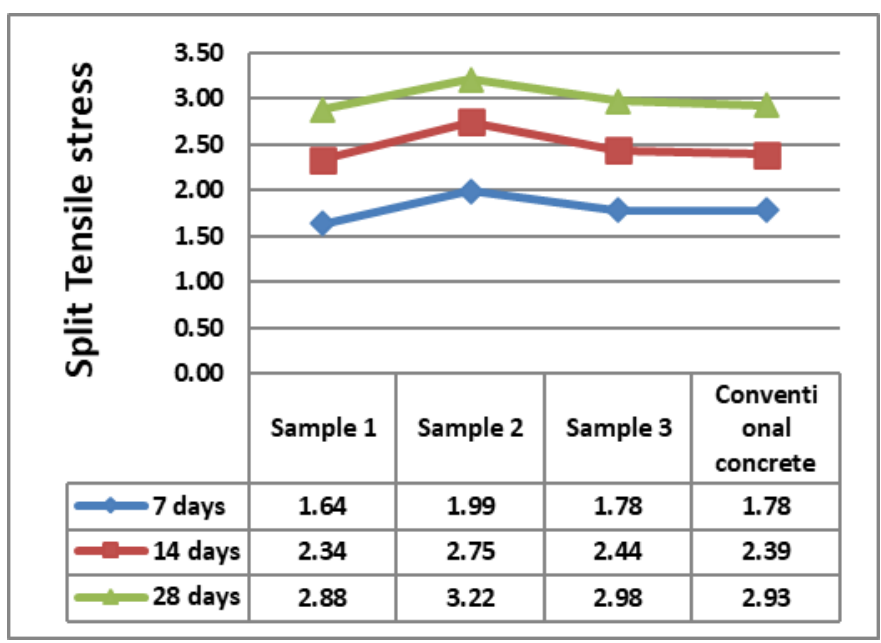

Figure 6 Graph Showing the Results of tensile strength test of HFRC.

\section{Flexural strength Test}

The concrete beam is placed in the testing machine in such a method the load shall be applied on the surface of the beam. The load shall be applied from the initial stage and then rises at a steady rate until the first crack of the specimen to the increasing load maximum up to the breakdown of the specimen. The highest load applied to the sample shall be noted and the exterior surface cracks are recorded at a different level. The samples are analyzed to find out the mechanical properties.

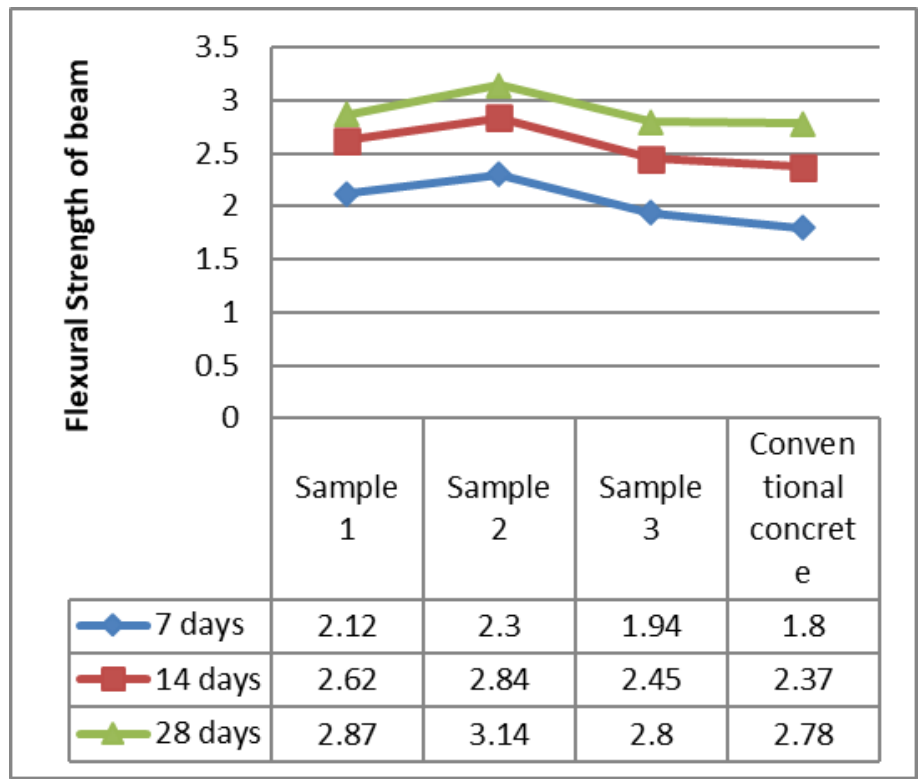

Figure 7 Graph Showing the Results of Flexural strength of HFRC.

\section{Result and Discussion}

The experimental results of adding Sisal fibre, banana fibre and Bamboo as a replacement of cement and coarse aggregates in concrete are represented in the work. The comparison of mechanical properties of the hybrid fibre reinforced concrete and conventional concrete is discussed. The hardened concrete properties are analyzed and compared for all the sample sets. 
We found that the use of Sisal fibre and banana fibre increases the flexural strength of the concrete. Thus, the building work with Bamboo concrete is environmentally safe and also economical. Sisal fibre and banana fibre can be used as a partial alternate for cement which will reduce the cost of cement in concrete and also diminish the expenditure of construction. Therefore, it is safe to swap the cement in practically with $1.5 \%$ Sisal fibre and banana fibre to obtain good strength parameters. It also enhances the workability of fresh concrete. It is proved that the flexural strength is enlarged up to the optimal level of replacement of Sisal fibre, banana fibre and Bamboo. The optimum percentage of replacement Sisal fibre and banana fibre by cement is $1.5 \%$ and Bamboo by coarse aggregate at $15 \%$. Adjustment of water level in mix design is balanced by adding a super plasticizer by $0.1 \%$ of water, thus results in good workability of concrete. Reduction in cement content did not cause any violent result in strength parameters. 7 days, 14days \& 28 days compressive strength, split tensile strength and flexural strength is extra than the conventional light concrete. The hybrid fibre reinforced concrete with Sisal fibre, banana fibre and bamboo is shows good result in strength characteristics.

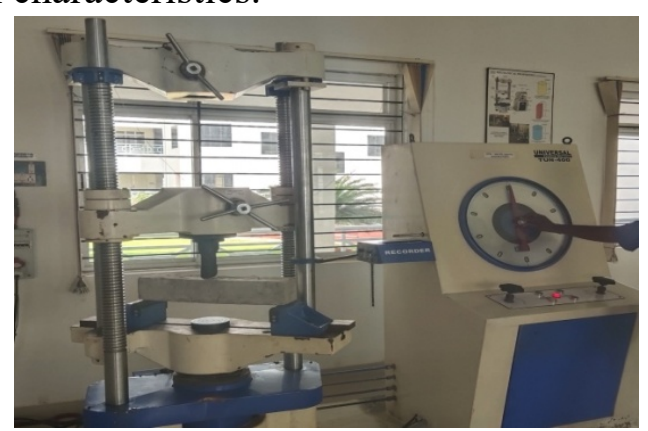

Figure 8 Experimental setup

\section{Conclusion}

It is proved that the flexural strength is enlarged up to the optimal level of replacement of Sisal fibre, banana fibre and Bamboo as $27 \%$. The optimum percentage of replacement Sisal fibre and banana fibre by cement is $1.5 \%$ and Bamboo by coarse aggregate at $15 \%$.

\section{References}

[1] Srinivasa Rao Naraganti, Rama Mohan Rao Pannem, Impact resistance of hybrid fibre reinforced concrete containing sisal fibres, Ain Shams Engineering Journal(ASEJ) 10 (2019) 297305. https://doi.org/10.1016/j.asej.2018.12.004

[2]Venkateshwaran.S, Kalaiyarrasi. A. R, Sisal Fiber Reinforced Concrete, Journal of Emerging Technologies and Innovative Research (JETIR) 5 (2018) 65-69.

[3]Radha K T Sumithra, ABS Dadapheer, Experimental Investigation on The Properties of Sisal Fibre Reinforced Concrete, International Research Journal of Engineering and Technology (IRJET) 04 (2017) 2774-2777.

[4]Chao-Lung Hwang, Vu-An Tran, Jhih-Wei Hong and You-Chuan Hsieh, Effects of short coconut fiber on the mechanical properties, plastic cracking behavior, and impact resistance of cementitious composites, Construction and Building Materials (CBM) 127 (2016) 984-992. https://doi.org/10.1016/j.conbuildmat.2016.09.118 
[5]Karunya Latha V, B. Beeraiah, Natural Sisal Fibre Reinforced Concrete with Experimental Studies, International Research Journal of Engineering and Technology (IRJET), 06 (2019) 1419 $-1423$

[6]Raghuveer H. Desai, L. Krishnamurthy, T. N. Shridhar, Effectiveness of Banana(Betel) Fiber as a Reinforcing Material in Eco-friendly Composites: A Review, Indian Journal of Advances in Chemical Science (IJACS) (2016) $27-33$.

[7]Syed Viqar Malik, Anil Achyut Kunte(2020),Structural Behavior Due to Hybridization of Sisal and Nylon Fibers in Concrete, International Journal of Recent Technology and Engineering (IJRTE) 8 (2020) 1875 - 1879. https://doi.org/10.35940/ijrte.F7122.038620

[8]Anayatullah Bhat, Zishan Raza Khan, Behaviour of Autoclaved Aerated Concrete Blocks using Alkali-Resistant Glass Fibre as Additive, International Journal of Recent Technology and Engineering (IJRTE) 8 (2020) 3508 -3513. https://doi.org/10.35940/ijrte.F8478.038620

[9]Kanchidurai S., Nanthini T. and Jai Shankar P, Experimental Studies On Sisal Fibre Reinforced Concrete With Groundnut Shell Ash, ARPN Journal of Engineering and Applied Sciences(ARPN) 12 (2017) 5914 - 5920

[10] MałgorzataPająk, TomaszPonikiewski, Experimental Investigation on Hybrid Steel Fibers Reinforced Self-compacting Concrete under Flexure, Procedia Engineering(PE), 2017, Pages 218-225. https://doi.org/10.1016/j.proeng.2017.06.207

[11] K.F.Li, C.Q.Yang, Effects of hybrid fibers on workability, mechanical, and time-dependent properties of high strength fiber-reinforced self-consolidating concrete, Construction and Building Materials(CBM), 277 (2021), 1 -12. https://doi.org/10.1016/j.conbuildmat.2021.122325

[12] Saravanakumar P, Sivakamidevi M, An experimental study on hybrid fiber reinforced concrete beams subjected to torsion, Materials today Proceeding(MTP) 2021. https://doi.org/10.1016/j.matpr.2020.12.1003

[13] TaoWu, LixinSun, Uniaxial performance of circular hybrid fibre-reinforced lightweight aggregate concrete columns, Engineering Structures(ES), 238 (2021), 112263. https://doi.org/10.1016/j.engstruct.2021.112263

[14] Tuan KietTran, Ngoc ThanhTran, Enhancing impact resistance of hybrid ultra-high-performance fiber-reinforced concretes through strategic use of polyamide fibers, Construction and Building Materials(CBM), 271(2021), 121562.

https://doi.org/10.1016/j.conbuildmat.2020.121562

[15] Dia EddinNassani, Experimental and analytical study of the mechanical and flexural behavior of hybrid fiber concretes, Structures, 28 (2020), 1746-1755. https://doi.org/10.1016/j.istruc.2020.10.014

[16] Poongodi K, AlmasKhan et.al(2021),Strength properties of hybrid fibre reinforced quaternary blended high performance concrete, Materials today Proceeding(MSP), 39 (2021) 627-632. https://doi.org/10.1016/j.matpr.2020.09.007 